DOI: $10.4274 /$ tpa.46.79

\title{
Çocukluk çağı Hodgkin lenfoma hastalarının uzun dönem izlemlerinde kalp işlevlerinin doku Doppler ekokardiyografi yöntemi ile değerlendirilmesi
}

\author{
Evaluation of cardiac functions by tissue Doppler echocardiography in the \\ long term follow-up of patients with childhood Hodgkin Lymphoma
}

\author{
Ceyhun Bozkurt, Utku Arman Örün* , Ayşe Ulya Ertem, Burhan Öcal*, Gürses Şahin, Nazmiye Yüksek**, Sonay Incesoy Özdemir, Filiz Şenocak* \\ Dr Sami Ulus Çocuk Hastanesi, Çocuk Onkoloji Kliniği, Ankara, Türkiye \\ *Dr Sami Ulus Çocuk Hastanesi, Çocuk Kardiyoloji Kliniği, Ankara, Türkiye \\ **Zonguldak Karaelmas Üniversitesi Tıp Fakültesi, Çocuk Onkoloji Kliniği, Zonguldak, Türkiye
}

Özet

Amaç: Hodgkin lenfoma hastalarında tedavi ile ilişkili kardiyomiyopati yakınmasız da olabilen bir sorundur. Bu çalışmanın amacı Hodgkin lenfoma hastalarında potansiyel olarak var olan tedavi ile ilişkili kardiyomiyopatiye tanı konmada doku Doppler ekokardiyografi tekniğinin geleneksel ekokardiyografi tekniğine oranla bir üstünlüğünün olup olmadığının araştırılmasıdır.

Gereç ve Yöntem: En az dört yıl süreyle hastalıksız izlenen ve kalp yakınması olmayan 17 Hodgkin lenfoma hastası (12 erkek, 5 kız) ve kontrol grubu olarak 14 sağlıklı kişi (8 kız, 6 erkek) çalışmaya alındı. Hastaların kalp işlevleri M-mod, 2 boyutlu, renkli Doppler, CW Doppler ve pulse Doppler teknikleri ile değerlendirildi. Veri analizleri Statistical Package for Social Science for Windows 11,5 paket programı ve sırasıyla Shapiro Wilk, Student's t testi, Mann Whitney U, Fisher'in kesin sonuçlu ki-kare testleriyle yapıldı. Çalışma için hastane yerel etik kurul onayı alındı (07.05.2007/no:5639).

Bulgular: Her iki grup geleneksel ekokardiyografi yöntemleri ile ejeksiyon fraksiyonu ve kısalma fraksiyonu açısından değerlendirildiğinde gruplar arasında fark gözlenmedi (sırasıyla $p=0,302$ ve $p=0,860$ ). Her iki grup sol ventrikül izovolemik ivmelenme zamanı açısından değerlendirildiğinde ölçümler hasta grubunda kontrol grubuna oranla istatiksel olarak anlamlı biçimde kısa bulundu (p:0,038). Miyokardiyal performans indeksi ölçümleri ve sol ventrikül izovolemik kasılma zamanı ölçümleri açısından değerlendirildiklerinde ise yapılan ölçümler hasta grubunda kontrol grubuna oranla istatistiksel olarak anlamlı biçimde uzamış olarak bulundu (sırasıyla $p=0,029$ ve $p=0,049$ ).

Çıkarımlar: Sol ventrikül izovolemik ivmelenme zamanı, miyokardiyal performans indeksi ve sol ventrikül izovolemik kasılma zamanlarının tedavi ile ilişkili kardiyomiyopatiyi erken belirlemede önemli ölçümler olduğu sonucuna varılmıştır. (Türk Ped Arş 2011; 46: 228-33)

Anahtar sözcükler: Antrasiklin, doku Doppler ekokardiyografi, Hodgkin lenfoma, kardiyotoksisite, yan etki

\section{Summary}

Aim: Treatment-associated cardiomyopathy which is one of the side effects of treatment, can be asymptomatic in Hodgkin lymphoma patients. The aim of this study was to find out whether tissue Doppler echocardiography was superior to conventional echocardiography in determining potential cardiac problems in the patients diagnosed with Hodgkin lymphoma.

Material and Method: A total of 17 Hodgkin lymphoma patients (12 males, 5 females), and whose treatment had been stopped for at least 4 years were being followed-up with disease-free status and without cardiac symptoms and a control group of 14 healthy persons ( 8 males, 6 females) were included in the study. The cardiac functions of the patients were evaluated by M-mode, 2 dimentional, colour Doppler, CW Doppler and pulse Doppler techniques. Data analyzes were evaluated by program of Statistical Package for Social Science for Windows 11.5, and Shapiro Wilk, Student's t testi, Mann Whitney U, Fisher's exact chi square tests, respectively. Hospital ethic committee consent was received for the study (07.05.2007/no:5639). Results: There were no statistical differences between the two groups ( $p=0.302$ and $p=0.860$ respectively) when both groups were evaluated in terms of ejection fraction and fraction shortening by conventional echocardiography technique. Evaluation of both groups for the left ventricle isovolumic contraction time revealed a statistically significant longer time in the patient group compared with the control group ( $p$ : 0.038 ). The results were found longer in the patient group compared with the control group when both groups were evaluated in terms of myocardial performance index parameters and the left ventricle isovolumic contraction time parameters ( $p=0.029$ and $p=0.049$, respectively).

Conclusions: We concluded that the left ventricle isovolumic contraction time, the left ventricle isovolumic acceleration time and myocardial performance index tests are important parameters for the early detection of cardiac pathologies that may develop in relation to chemotherapy. (Turk Arch Ped 2011; 46: 228-33)

Key words: Anthracycline, cardiotoxicity, Hodgkin lymphoma, side effect, tissue Doppler echocardiography

Yazışma Adresi/Address for Correspondence: Dr. Ceyhun Bozkurt, Dr Sami Ulus Çocuk Hastanesi, Çocuk Onkoloji Kliniği Ankara, Türkiye E-posta: bozkurt.ceyhun@gmail.com Geliş Tarihi/Received: 05.01.2011 Kabul Tarihi/Accepted: 03.03.2011 


\section{Giriş}

Gelişmekte olan ülkelerde son yıllarda çocukluk çağı Hodgkin lenfoma hastalı̆ıının sağaltımında belirgin ilerlemeler kaydedilmiştir (1). Bununla birlikte birincil hastalığın tedavisi için kullanılan ilaç ve radyoterapiye bağlı yan etkiler önemli bir sorun olarak karşımıza çıkmaktadır. Radyoterapi ve antrasiklin grubu ilaçların birlikte kullanımı ile birlikte gelişen kardiyomiyopati bunlardan birisidir. Her iki tedavi şeklinin birlikte kullanımı bu tabloya neden olabildiği gibi tedavi seçeneklerinden her birisi de potansiyel kardiyotoksik etki taşımaktadır. Yapılan çalışmalar ile sadece kemoterapi alıp radyoterapi almayan Hodgkin lenfoma hastalarında da yüksek oranda kalp ile ilgili yan etki gösterilmiştir (2). Kullanılan kemoterapotikler içinde bulunan antrasiklin grubu ilaçlar bu tablonun oluşmasında önemli bir olumsuz etkendir.

Uzun dönem yaşayan Hodgkin lenfomalı hastalar kalp işlevleri açısından yakınmasız ve sorunsuz görünseler bile gerçek kalp sorun oranı beklenenin üstündedir $(3,4)$. Bu oran bazı serilerde $\% 57$ gibi yüksek bir rakama ulaşmakta ve bu sorunun gelişiminde toplam antrasiklin dozu (özellikle 250-300 $\mathrm{mg} / \mathrm{m}^{2}$ 'nin üstündeki değerler), hastanın erken ya da geç yaşta antrasiklin tedavisi alması, kız cinsiyet, radyasyon tedavisi, yüksek doz tedaviler gibi etkenlerin önemli rol oynadığı ileri sürülmektedir $(3,5)$. Bu kalp komplikasyonunu belirlemede en sık kullanılan tetkik, sol ventrikül ejeksiyon fraksiyonu ve kısalma fraksiyonunu ölçen girişimsel olmayan iki boyutlu ekokardiyografi tetkikidir. Düşük ya da yüksek doz ile dopamin stres ekokardiyografi, ekokardiyografi ile miyokard gerginliğini ölçme, egzersiz elektrokardiyografi değerlendirmesi, kan atriyal natriüretik hormon ölçümü, kalp manyetik rezonansı gibi testler ile uzun dönemde gelişebilecek kalbe ait yan etkileri erken değerlendirmede klasik ekokardiyografiye oranla daha iyi sonuçlar elde edildiğini bildiren çalışmalar vardır (6-9). Fakat tüm bu çalışmalara rağmen uzun dönemde gelişebilecek kardiyomiyopatiyi erken belirlemede uygun bir test henüz yoktur (10). Doku Doppler ekokardiyografi kalp duvar kaslarının hareketlerinin hızlanma gidişatını ölçen yeni bir tekniktir. Bu tetkikin başııca üstünlükleri hastaya ait yaş, kan basıncı, kalp atım hızı gibi etkenlerden etkilenmemesidir. Doku Doppler ekokardiyografi ölüme yol açabilecek kalp patolojilerini erkenden saptayabilmektedir $(11,12)$. Doku Doppler ekokardiyografi ile çocukluk çağı malinitesi olan hastalarda uzun dönem yan etkilerinin değişik alt değişkenler ile değerlendirildiği ve kardiyomiyopati tablosunu geleneksel yöntemlere oranla daha erken saptadığını bildiren çalışmalar vardır $(12,23,24,26,27)$ Bu çalışma ile radyoterapi almamış çocukluk çağı Hodgkin lenfoma olgularında kemoterapotiklerin uzun dönem kalbe ait yan etkilerini değerlendirmede doku Doppler ekokardiyografi tekniğinin geleneksel ekokardiyografi tekniğine bir üstünlüğünün olup olmadığının araştıııması amaçlanmıştır.

\section{Gereç ve Yöntem}

Bu çalışmaya Dr. Sami Ulus Hastanesi Çocuk Onkolojisi Kliniği'nde 1994-2003 yılları arasında Hodgkin lenfoma tanı ve tedavisi almış, radyoterapi almamış, en az dört yıl süreyle tedavisi kesilmiş ve hastalıksız olarak izlenen ve tedavileri esnasında düzenli aralıklar ile geleneksel ekokardiyografi tetkiki yapılan 17 Hodgkin lenfoma hastası (12 erkek, 5 kız) ve kontrol grubu olarak da 14 sağlıklı kişi (8 erkek, 6 kız) alındı. Ekokardiyografik çalışma Vivid Pro7 cihazı ile $3 \mathrm{MHz}$ prob kullanılarak yapıldı. Sağ ventrikül ve sol ventrikül boyutları, çıkım yolları, kapak yetersizlikleri, darlıkları; M-mod, iki boyutlu, renkli Doppler, CW Doppler ve pulse Doppler ile değerlendirildi. İșlem elektrokardiyografi monitörizasyonu eșliğinde yürütüldü. Doku Doppler çalışması 3 MHz'lik prob ile yapıldı. Çalışma pozisyonu olarak apikal dört boșluk pozisyon seçildi. Temiz, artıklardan arınmış görüntü alınması için Doppler "gain" düşüldü. Ekokardiyografi cihazının filtre formatı kullanıldı. Doppler sinyalleri $100 \mathrm{~mm} / \mathrm{sn}$ hızda kaydedildi. Doku hareketlerinin açık bir şekilde görüntülenebilmesi için gate 2-3 mm'ye kadar azaltıldı. Sol ventrikül bazal kısmından izovolemik gevşeme zamanı, izovolemik kasılma zamanı, sistol sırasında oluşan miyokardiyal hız, erken diyastolde oluşan miyokardiyal hız, geç diyastolde oluşan hız, ejeksiyon süresi, izovolemik kasılma ivmelenmesi, izovolemik kasılma zamanında ventrikülün yaptığı ivmelenme ölçümleri alındı.

Hastaların tedavilerinin bitiminden sonra ortanca izlem süresi 108 (54-174) ay olarak bulundu. Bulgulu ya da bulgusuz olsun daha önceden kalp sorunu saptanmış olan hastalar çalışma dışında tutuldu. Hastaların evrelemesi Ann-Arbor evreleme sistemine göre yapıldı. Hodgkin lenfoma tanısı almış hastalardan beși adriyablastin, bleomisin, vinblastin, dakarbazin, altısı siklofosfamid, onkovin, prokarbazin, prednizolon, altısı ise ardışık adriyablastina, bleomisin, vinblastin, dakarbazin-siklofosfamid, vinkristin, prokarbazin, prednizolon tedavisi gördü. Erken evre (evre 1-2) hastalara altı kür siklofosfamid, onkovin, prokarbazin, prednizolon ya da adriyablastina, bleomisin, vinblastin, dakarbazin; ileri evre (evre 3-4) hastalara 12 kür adriyablastina, bleomisin, vinblastin, dakarbazin-siklofosfamid, vinkristin, prokarbazin, prednizolon ardlşık tedavileri verildi. Hodgkin lenfoma tanılı hastaların aldığı toplam antrasiklin ve alkilleyici ajan dozları hesaplandı. Hiçbir hastaya radyoterapi uygulanmadı. Hastalara ait klinik bilgiler Tablo'1 de özetlenmiştir.

$\mathrm{Bu}$ çalışma için hastane yerel etik komite onayı ve tüm hasta ya da hasta yakınlarına yapılan çalışma ile ilgili ayrıntıı bilgi verilerek kendilerinden bu çalışma için onay alındı (07.05.2007/no:5639).

\section{İstatistiksel analiz}

Verilerin analizi SPSS (Statistical Package for Social Science) for Windows 11,5 paket programında yapıldı. Sürekli değişkenlerin dağılımının normale yakın olup olmadığı Shapiro Wilk testi ile incelendi. Tanımlayıcı istatistikler, sürekli değişkenler için ortalama \pm standart sapma veya ortanca (çeyrekler arası genişlik) biçiminde, sayısal değişkenler ise olgu sayısı ve (\%) şeklinde gösterildi. Gruplar arasında ortalamalar yönünden istatistiksel olarak anlamlı farkın olup olmadığı Student's t testi ile ortanca değerler yönünden farkın önemliliği ise Mann Whitney $U$ testiyle değerlendirildi. Nominal değişkenler Fisher'in kesin sonuçlu ki-kare testi ile incelendi. $p<0,05$ için sonuçlar istatistiksel olarak anlamlı kabul edildi. 


\section{Bulgular}

Toplam 31 kişi bu çalışmaya alındı. Bunlardan 17'si Hodgkin lenfoma hastası; 14'ü ise kontrol grubunu oluşturmaktaydı. Hodgkin lenfoma tanılı hastaların ortalama yaşı $180,1 \pm 48,6$ ay; kontrol grubunun ortalama yaşı ise $184,3 \pm 28,9$ ay idi $(\mathrm{p}=0,766)$. Hodgkin lenfoma tanılı hastaların 12'si erkek 5’i ise kız idi. Sağlıklı grubun 8'i erkek, 6'si ise kız idi ( $p=0,477)$. Her iki grup yapılan geleneksel ekokardiyografi tekniği ile ejeksiyon fraksiyon ve kısalma fraksiyonu açısından karşılaştııılığında gruplar arasında istatiksel olarak fark gözlenmedi (sırasıyla p: 0,302 ve p: 0,860). İki grup arasında doku Doppler ekokardiyografi tetkikinin ölçümleri açısından karşılaştırma yapıldığında; Hodgkin lenfoma grubunda sol ventrikül izovolemik kasılma zamanı (LVBICT) 150,12 $\pm 44,72$ (msn), kontrol grubu-

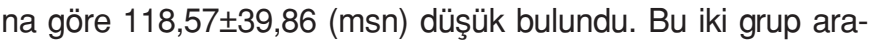
sında istatistiksel fark sınırda bulundu (p: 0,049). Sol ventrikül izovolemik ivmelenme zamanı (LVBIVA) Hodgkin lenfoma gru-

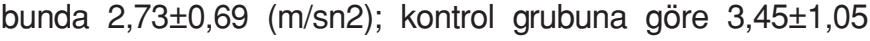
(m/sn2) düşük bulundu. Bu iki grubun değerlendirmeleri arasında istatistiksel olarak anlamlı farklılık bulundu (p: 0,038). Miyokard performans indeksi (MPI) Hodgkin lenfoma grubunda $1,06(0,63)$; kontrol grubunda ise $0,77(0,33)$ bulundu. $\mathrm{Bu}$ değerler arasında istatistiksel olarak anlamlı bir farklılık bulundu (p: 0,029). Miyokard performans indeksi ile toplam ilaç dozları arasında belirgin bir ilișki gözlenmedi. Diğer bakılan ölçümler açısından gruplar arasında bir farklılık gözlenmedi. Değişkenler arasındaki değerlendirmenin özeti Tablo'2 de verilmiştir.

Tablo 1. Hastaların klinik özellikleri

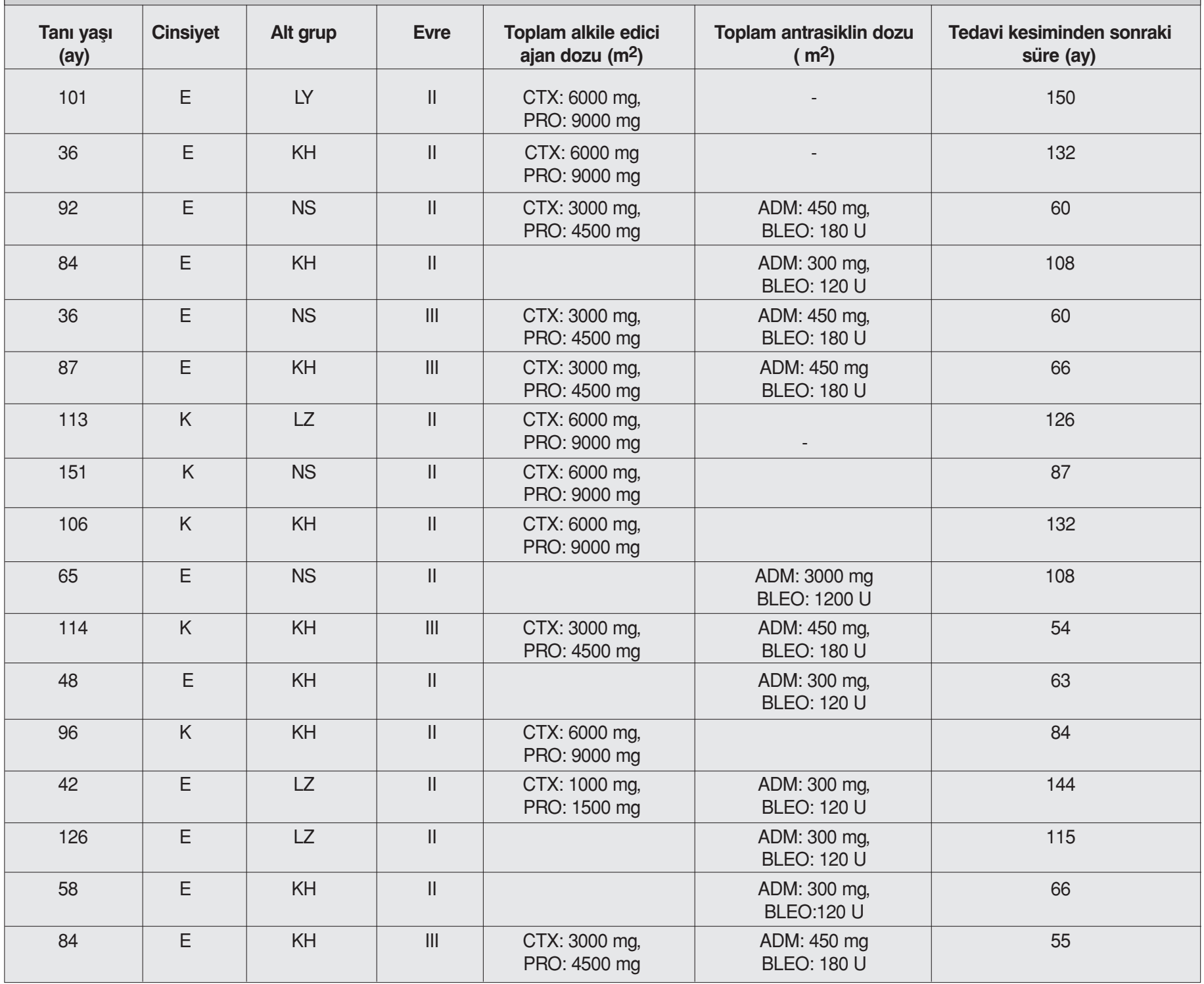

Kısaltmalar: ADM: Adriyablastin, BLEO: Bleomisin, CTX: Siklofosfamid, E: Erkek, KH: Karışık hücreli, K: KIz, LD: Lenfositten yoksun, LZ: Lenfositten zengin, mg: Miligram, NS: Nodüler sklerozan, PRO: Prokarbazin, U: Ünite 


\section{Tartıșma}

Antrasiklin grubu ilaç kullanan hastalarda gerek erken dönem dediğimiz tedavinin ilk bir yılında; gerekse tedavi sonrası 20 yıla kadar uzanan uzun süreli izlemlerinde (kronik dönem ) gelişen kardiyotoksisite iyi bilinen bir durumdur. Bu klinik patolojiye antrasiklin tedavisi sonucu ortaya çıkan serbest radikaller ve superoksitlerin uyarması ile gelişen miyozitlerdeki apopitoz tablosunun yol açtığı düșünülmektedir. Bu etki dozdan bağımsız olabilmekle birlikte kemoterapotiklerin toplam dozlarının artmasına koşut olarak artabilmektedir (13). Öte yandan literatürde özellikle kemik iliği nakli yapılmış hastalarda yüksek doz alkilleyici ajanlar sonrası gelişen kardiyomiyopati bilinen bir durum olmakla birlikte, bilinen dozda alkilleyici ajanları kullanan hastalarda da gelişen kardiyotoksisite olguları bildirilmektedir (14). Bu durumun gelişiminde siklofosfamidin kalpte hücre apopitozunu uyarmasının, tedavi sonucu serum karnitin düzeyinin azalmasının ve serum lipit düzeyindeki bozuklukların rol oynadığı düşünülmektedir $(13,15,16)$. Antrasiklin grubu ilaçlar kullanmış kanser hastalarında gelişen kardiyovasküler sorunların önemli bir kısmı uzun bir süre

\section{Tablo 2. Klinik ve demografik özelliklerin gruplar arasında incelenmesi}

\begin{tabular}{|l|c|c|c|}
\hline \hline Değişkenler & Hasta grubu (s=17) & Kontrol grubu (s=14) & $\mathbf{p}$ \\
\hline Yaş & $180,1 \pm 48,6$ & $184,3 \pm 28,9$ & $0,766^{\mathrm{a}}$ \\
\hline Cinsiyet E/K & $12 / 5$ & $8 / 6$ & $0,477^{\mathrm{b}}$ \\
\hline LVBS & $0,09 \pm 0,02$ & $0,09 \pm 0,02$ & $0,951^{\mathrm{a}}$ \\
\hline LVBE & $0,20 \pm 0,03$ & $0,22 \pm 0,04$ & $0,177^{\mathrm{a}}$ \\
\hline LVBA & $0,08(0,02)$ & $0,08(0,03)$ & $0,570^{\mathrm{b}}$ \\
\hline LVBICT & $150,12 \pm 44,72$ & $118,57 \pm 39,86$ & $0,049 \mathrm{a}$ \\
\hline LVBSS & $208,00 \pm 37,67$ & $231,50 \pm 33,81$ & $0,081^{\mathrm{a}}$ \\
\hline LVBES & $120,76 \pm 20,16$ & $111,50 \pm 18,27$ & $0,195^{\mathrm{a}}$ \\
\hline LVBAS & $61,59 \pm 17,22$ & $61,57 \pm 11,37$ & $0,998^{\mathrm{a}}$ \\
\hline LVBIRT & $70,18 \pm 12,75$ & $68,64 \pm 19,70$ & $0,804^{\mathrm{a}}$ \\
\hline LVBIVA & $2,73 \pm 0,69$ & $3,45 \pm 1,05$ & $0,038^{\mathrm{a}}$ \\
\hline LVBSA & $0,96 \pm 0,39$ & $0,91 \pm 0,30$ & $0,659^{\mathrm{a}}$ \\
\hline LVBEA & $3,85 \pm 0,80$ & $3,87 \pm 1,00$ & $0,941^{\mathrm{a}}$ \\
\hline LVBAA & $2,10(1,68)$ & $2,65(2,40)$ & $0,279^{\mathrm{b}}$ \\
\hline EF & $70,77 \pm 7,86$ & $68,06 \pm 6,11$ & $0,302^{\mathrm{a}}$ \\
\hline FS & $39,00(11,50)$ & $36,00(7,50)$ & $0,860^{\mathrm{b}}$ \\
\hline TEI & $1,06(0,63)$ & $0,77(0,33)$ & $0,029^{\mathrm{b}}$ \\
\hline
\end{tabular}

Kısaltmalar: a: Student's t testi, b: Fisher'in kesin sonuçlu ki-kare testi, c: Mann Whitney U testi. , EF:Ejeksiyon fraksiyonu (\%), , FS:kısalma fraksiyonu, LVBA:Sol ventrikül bazal A amplütüd (m/sn), LVBAA:Sol ventrikül A akselerasyonu (m/sn2 (\%),LVBAS:Sol ventrikül bazal A süresi (msn), LVBE:Sol ventrikül bazal E amplütüd (m/sn), LVBEA:Sol ventrikül $E$ akselerasyonu (m/sn2), LVBES:Sol ventrikül bazal E süresi (msn), LVBICT:Sol ventrikül izovolemik kasılma zamanı (msn), LVBIRT: Sol ventrikül izovolemik gevşeme zamanı (msn), LVBIVA:Sol ventrikül izovolemik akselerasyon zamanı (m/sn2), LVBS:Sol ventrikül bazal $S$ amplütüd (m/sn), LVBSA:Sol ventrikül $S$ akselerasyonu (m/sn2), LVBSS:Sol ventrikül bazal S süresi (msn), TEl:Tei indeks yakınmasız olabilmektedir. Alkilleyici ajanlar ve antrasiklinler ile tedavi edilen hastalarda kardiyomiyopati izlemi geleneksel ekokardiyografi tekniği ile ejeksiyon fraksiyonu ve kısalma fraksiyonunun ölçümü ile yapılmaktadır. Bu tetkikler hastaların sistolik işlevlerini değerlendirmede kullanılmaktadır. Oysa kardiyomiyopati gelişen hastalarda ilk olarak diyastolik işlevlerin bozulduğu varsayılmaktadır (5). Bu nedenle bu hastalarda olası gelişebilecek kardiyomiyopatiyi erken saptama ve değerlendirme için sadece sistolik değil, diyastolik işlevlerin de değerlendirilmesi gerekmektedir. Doku Doppler ekokardiyografi tekniğinin hem sistolik hem de diyastolik işlevler hakkında bilgi verdiği için geleneksel ekokardiyografi tekniğine oranla daha etkin bir teknik olduğu düşünülmektedir (4).

Illk defa Tei (17) tarafından belirlenen ve bu nedenle de Tei indeksi olarak da bilinen MPI izovolemik kasılma ve gevşeme zamanlarının toplamının ejeksiyon zamanına bölümü ile elde edilen bir ölçümdür. Miyokard performans indeksi miyokardın sistolik ve diyastolik işlev bozuklukları ile uyumlu olan kalp hızı ve kan basıncından bağımsız olan basit, tekrarlanabilir bir testtir (6). Miyokardiyal performans indeksinin doğuştan kalp hastalıkları, kalp yetersizliği, koroner kalp hastalığı, kalp kapak hastalıkları, pulmoner hipertansiyon ve ilaca bağlı kardiyotoksisitenin kalp üstündeki etkisini erken göstermede uygulanabilir bir ölçüm olduğu düşünülmektedir (18). Santin ve ark. (19) yaptığı çalışmada kemoterapi ve radyoterapi alan hastalarda MPI indeksi açısından kontrol grubuna oranla belirgin düşüş gözlendiği, ancak sadece kemoterapi alanlar ile kontrol grubu arasında belirgin bir fark olmadığı gösterilmiştir. Bizim çalışmamızda ise bu bulguların tersine gerek antrasiklin; gerekse alkilleyici ajan içeren tedavi protokolleri ile tedavi gören hasta grubunda radyoterapi almamalarına rağmen MPI değeri kontrol grubuna oranla anlamlı düşük bulunmuştur. Hastanemizde daha önce Öcal ve ark. (20) 35 adet çocukluk çağı malin hastalık tanısı almış hasta grubunda yaptığı çalışmada antrasiklin tedavisi alan hastaların MPI indeksinde kontrol grubuna oranla belirgin düşüş olduğu gösterilmişti. Fakat bu düşüklük ile alınan kemoterapik ilacın toplam dozu arasında bir bağlantı kurulamamıştı. larussi ve ark. (21), çocukluk çağı Hodgkin lenfoma tanılı hastalar ile ilgili yaptıkları çalışmada ise bizim çalışmamızla uyumlu olarak kemoterapi alanlarda sağlıklı gruba oranla aynı LVBICT ve MPI düşüklüğü gözlemişler; bu düşüklük ile antrasiklin dozu ve radyoterapi alınması arasında bir ilişki bulamamışlardır. Ayrıca Karakurt ve ark. (22) tedavi olarak antrasiklin grubu içeren tedavi protokolleri alan ve hiçbir hastanın mediyastinal radyoterapi almadığı çocukluk çağı malinitesi olan hastalarda yaptıkları çalışmada MPI değerini sağlıklı gruba oranla istatistiksel olarak anlamlı düşük bulmuşlar ve bu düşük değerlerin de hastaların aldığı toplam antrasiklin dozları ile anlamlı koşut olduğunu belirlemişlerdir. Hastaların aldığı antrasiklin ya da diğer kardiyotoksik ilaç dozunun artması ile birlikte gelişebilecek kardiyomiyopatinin şiddetinde artma bekIenen bir bulgudur. Bizim çalışmamızda toplam ilaç dozları ile oluşan kardiyomiyopati arasında anlamlı istatistiksel ilişkinin elde edilememesi çalışmamızdaki olgu sayısının azlığından kaynaklanmış olabilir. Yıldırım ve ark. (23) lenfoma ve solid tümör tanısı ile tedavi almış çocukluk çağı grubunda yaptığı çalışmada ise sol ventrikül akım MPI değerinin sol ventrikül 
duvar MPI değerine göre hastalarda gelişen kardiyomiyopatiyi belirlemede daha iyi bir gösterge olduğunu ileri sürmektedirler.

İzovolemik kasılma döneminde ölçülen hızın tepe değeri ile bazalden tepe oluşmasına kadar geçen süre kullanılarak hesaplanan izovolemik ivmelenme (IVA) değeri, özellikle hemodinamik değişikliklerden etkilenmeden sistolik işlevleri değerlendirmemizi sağlayan bir ölçümdür (24). Bizim çalışmamızda tedavi alan grupta ejeksiyon fraksiyon değeri, kısalma fraksiyonunun her iki grupta istatiksel olarak farklı olmamasına rağmen LVBIVA değeri kontrol grubuna oranla anlamIı yüksek bulunmuştur. Bu ölçüm diyastolik işlevlerin bozulmasından sonra ortaya çıkan sistolik işlev bozukluğunun ilk habercilerinden biri olabilir. Sistolik işlev bozukluğunu gösteren ventrikül izovolemik kasılma ve gevşeme ivmelenme zaman değerlerinin ön yük ve ard yükten etkilenmeden sistolik işlevleri erken göstermede iyi bir ölçüm olduğunu bildiren çalışmalar vardır (25). Dorup ve ark. (5) çocukluk çağı Wilms tümör ve akut lenfoblastik lösemili hastaları içeren çalışmalarında diyastolik erken hızlanma bozuklukları özellikle kısalma fraksiyonu \%25'in altında olan olgularda saptamışlardır. Toplam aldığı antrasiklin dozu $250 \mathrm{mg} / \mathrm{m}^{2 \prime}$ nin üstünde olan hastalarda ventrikül gevşeme zamanında uzama ve ivmelenme zamanında kısalma gözlemişler ve bu bulguların diyastolik işlevlerin sistolik işlev bozulmasından daha önce ortaya çıkmaya başladığının belirteci olduğunu vurgulamışlardır. Baysal ve ark. (26) çocukluk çağı tümörü olan 20 olguda yaptığı çalışmada antrasiklin tedavisi alan hastaların LVBICT ve sol ventrikül izovolemik gevşeme zamanı değerleri kontrol grubuna oranla yüksek bulunmuştur. Aynı şekilde Öcal ve ark. (20) yaptığı çalışmada kemoterapi alan kanser hastalarında MPI değerindeki anlamlı farklılık dışında LVBICT'nin de uzadığı gösterilmiști. Bizim çalıșma grubumuzda ise sadece LVBICT istatiksel olarak sınırda anlamlı uzamış olarak gözlenmiştir. Bu farklılık göreceli olarak düşük antrasiklin tedavisi almış hasta sayısından; Baysal ve ark. (26) hastalarının bir kısmının radyoterapi almasından kaynaklanabilir.

Bizim çalışmamızda sadece antrasiklin; antrasiklin ve alkilleyici ajan tedavisi alan ya da antrasiklin tedavisi almayıp sadece alkilleyici ajan alan hastalar arasında kardiyotoksisite açısından bir fark gözlenmedi. Bu sonuç hasta sayısının azlığından kaynaklanmış olabilir. Sonuç olarak sadece antrasiklin tedavisi alan hastaların değil alkilleyici ajan tedavisi alan hastaların da kardiyomiyopati yönünden uzun dönem izlemi gereklidir. Doku Doppler ekokardiyografi tekniği özellikle MPI ölçümü bu hastalarda oluşabilecek kardiyomiyopatiyi özellikle diyastolik işlevleri iyi değerlendirme özelliği nedeniyle erken saptamada yararlı bir yöntem olabilir. Çalışmamızda bakılan ve kontrol grubuna oranla istatiksel olarak sınırda anlamlı farklıı̆ı olan ( $p: 0,049)$ LVBICT ve anlamlı farklıı̆ı olan ( $p: 0,038)$ LVBICT testlerinin klinik önemi konusunda literatürdeki çalışmalar kısıtıdır. Çalışmamızda ivmelenme zamanının anlamlı farkı dikkate değerdir. Bu nedenle MPI ile birlikte değerlendirilmesi, kalp etkilenimini göstermek açısından önemli olabilir. Bu konuda daha sağlıklı verilerin alınabilmesi için tanı anından itibaren doku Doppler ekokardiyografi tetkikleri ile seri incelemelerin yapıldığı geniş katılımlı, ileri dönük çalışmaların yapılması gerekmektedir.

\section{Çalışmanın kısıtııı̆ı}

Çalışmamızın başlıca eksiği hasta sayısı olarak küçük bir grubu içermiş olmasıdır. Ayrıca hastaların tedavi öncesi ve tedavi süresince doku Doppler kayıtlarının olmaması ayrı bir eksikliktir. Bu tip eksiklikler planlı, geniş serili ileri dönük çalışmalar ile önlenebilir.

\section{Çıkar çatışması ve maddi kaynak bildirilmedi}

Yazarlar arasında bu çalışma ile ilgili bir çıkar çatışması yoktur. Bu çalışma için herhangi bir finansal kaynak alınmamıştır.

\section{Kaynaklar}

1. Büyükpamukçu $M$, Varan $A, A$, Akyüz $C$, et al. The treatment of childhood Hodgkin lymphoma: improved survival in a developing country. Acta Oncol 2009; 48: 44-51

2. Swerdlow AJ, Higgins CD, Smith $P$, et al. Myocardial infarction mortality risk after treatment for Hodgkin disease: a collaborative British cohort study. J Natl Cancer Inst 2007; 99: 206-14.

3. Kremer LCM, Van Der Pal HJH, Offringa M, et al. Frequency and risk factors of subclinical cardiotoxicity after anthracycline therapy in children: a systematic review. Ann Oncol 2002; 13: 819-29.

4. Adams MJ, Lipsitz SR, Colan SD. Cardiovascular status in long-term survivors of Hodgkin's disease treated with chest radiotherapy. J Clin Oncol 2004; 22: 3139-48.

5. Dorup I, Levitt G, Sullivan I, et al. Prospective longitudinal assessment of late anthracycline cardiotoxicity after childhood cancer: the role of diastolic function. Heart 2004; 90: 1214-21.

6. Hamada H, Ohkubo T, Maeda M, et al. Evaluation of cardiac reserved function by high-dose dobutamine-stress echocardiography in asymptomatic anthracycline-treated survivors of childhood cancer. Pediatr Int 2006; 48: 313-20.

7. Pınarlı FG, Oğuz A, Tunaoğlu FS, et al. Late cardiac evaluation of children with solid tumors after anthracycline chemotherapy. Pediatr Blood Cancer 2005; 44: 370-7.

8. Mavikure-Groothuis AM, Weijers G, Groot-Loonen, et al. Interobsever, interobserver and intrapatient reliability scores of myocardial strain imaging with 2-D echocardiography in patients treated with anthracycline. Ultrasound Med Biol 2009; 35: 697-704.

9. Oberholzer K, Kunz RP, Dittrich M, et al. Anthracycline-induced cardiotoxicity: cardiac MRI after treatment for childhood cancer. Rofo 2004; 176: 1245-50.

10. Gharib MI, Burnett AK. Chemotherapy-induced cardiotoxicity: current practice and prospects of prophylaxis. Eur J Heart Fail 2002; 4: 235-42.

11. Mogelvang R, Sogaard P, Pedersen SA, et al. Cardiac dysfunction assessed by echocardiographic tissue Doppler imaging is an independent predictor of mortality in the general population. Circulation 2009; 119: 2679-85.

12. Nagy AC, Cserép Z, Tolnay E, et al. Early diagnosis of chemotherapyinduced cardiomyopathy: a prospective tissue Doppler imaging study. Pathol Oncol Res 2008; 14: 69-77.

13. Schimmel KJ, Richel DJ, Van Den Brink RB, et al. Cardiotoxicity of cytotoxic drugs. Cancer Treat Rev 2004; 30: 181-91.

14. Müller L, Kramm CM, Lawrenz W, et al. Recurrent atrial ectopic tachycardia following chemotherapy with ifosfamide. Pediatr Hematol Oncol 2004; 21: 307-11

15. Fatani AG, Darweesh AQ, Rizwan L, et al. Carnitine deficiency aggravates cyclophosphamide-induced cardiotoxicity in rats. Chemotherapy 2010; 56: 71-81.

16. Mythili Y, Sudharsan PT, Sudhahar V, et al. Protective effect of DL- $\alpha-$ lipoic acid on cyclophosphamide induced hyperlipidemic cardiomyopathy. Eur J Pharmacol 2006; 543: 92-6. 
17. Tei C. New non-invasive index for combined systolic and diastolic ventricular function. J Cardiol 1995; 26: 396-404.

18. Lakoumentas JA, Panou FK, Kotseroglou VK, et al. The Tei Index of myocardial performance: applications in cardiology. Hellenic $\mathrm{J}$ Cardiol 2005; 46: 52-8.

19. Santin JC, Deheinzelin D, Junior SP, et al. Late echocardiography assessment of systolic and diastolic function of the left ventricle in pediatric cancer survivors after anthracycline therapy. J Pediatr Hematol Oncol 2007; 29: 761-5.

20. Öcal B, Oğuz D, Karademir S, et al. Myocardial performance index combining systolic and diastolic myocardial performance in doxorubicin-treated patients and its correlation to conventional echo/Doppler indices. Pediatr Cardiol 2002; 23: 522-7.

21. larussi D, Pisacane C, Indolfi $P$, et al. Evaluation of left ventricular function in long-term survivors of childhood Hodgkin disease. Pediatr Blood Cancer 2005; 45: 700-5.
22. Karakurt C, Koçak G, Özgen U. Evaluation of the left ventricular function with tissue tracking and tissue Doppler echocardiography in pediatric malignancy survivors after anthracycline therapy. Echocardiography 2008; 25: 880-7.

23. Yıldırım A, Tunaoğlu FS. Pınarlı FG, et al. Tissue and flow myocardial performance index measurements taken during dobutamine stress echocardiography for early diagnosis of late anthracycline cardiotoxicity. Pediatr Cardiol 2010; 31: 96-105.

24. Özer N. Assessment of mitral stenosis with isovolumic myocardial acceleration. Turk Kardiyol Dern Arş 2008; 36: 395-6.

25. Hashimoto I, Bhat AH, Li X, et al. Tissue doppler-derived myocardial acceleration for evaluation of left ventricular diastolic function. J Am Coll Cardiol 2004; 44: 1459-66.

26. Baysal T, Köksal Y, Oran B, et al. Cardic functions evaluated with tissue doppler imaging in childhood cancers tretaed with anthracyclines. Pediatr Hematol Oncol 2010; 27: 13-23. 